\title{
An extended association screen in multiple sclerosis using 202 microsatellite markers targeting apoptosis-related genes does not reveal new predisposing factors
}

\author{
René Gödde*1, Stefanie Brune ${ }^{1}$, Peter Jagiello1, Eckhart Sindern², \\ Michael Haupts ${ }^{3}$, Sebastian Schimrigk ${ }^{4}$, Norbert Müller ${ }^{5}$ and Jörg T Epplen ${ }^{1}$
}

\begin{abstract}
Address: ${ }^{1}$ Department of Human Genetics, Ruhr-University, Bochum, Germany, ${ }^{2}$ Department of Neurology, Kliniken Bergmannsheil, RuhrUniversity, Bochum, Germany, ${ }^{3}$ Department of Neurology, Knappschaftskrankenhaus, Ruhr-University, Bochum, Germany, ${ }^{4}$ Department of Neurology, St. Josef-Hospital, Ruhr-University, Bochum, Germany and ${ }^{5}$ Department of Transfusion Medicine, Universitätsklinikum Essen, Essen, Germany

Email: René Gödde* - rene.goedde@ruhr-uni-bochum.de; Stefanie Brune - Steffi.Brune@web.de; Peter Jagiello - peter.jagiello@ruhr-unibochum.de; Eckhart Sindern - eckhart.sindern@ruhr-uni-bochum.de; Michael Haupts - michael.r.haupts@ruhr-uni-bochum.de; Sebastian Schimrigk - sebastian.schimrigk@ruhr-uni-bochum.de; Norbert Müller - norbert.mueller@medizin.uni-essen.de; Jörg T Epplen - joerg.t.epplen@ruhr-uni-bochum.de

* Corresponding author
\end{abstract}

Published: 05 September 2005

Journal of Negative Results in BioMedicine 2005, 4:7 doi:10.1 186/1477-575I-4-7

This article is available from: http://www.jnrbm.com/content/4/I/7

(C) 2005 Gödde et al; licensee BioMed Central Ltd.

This is an Open Access article distributed under the terms of the Creative Commons Attribution License (http://creativecommons.org/licenses/by/2.0), which permits unrestricted use, distribution, and reproduction in any medium, provided the original work is properly cited.
Received: 10 March 2005

Accepted: 05 September 2005

\begin{abstract}
Apoptosis, the programmed death of cells, plays a distinct role in the etiopathogenesis of Multiple sclerosis (MS), a common disease of the central nervous system with complex genetic background. Yet, it is not clear whether the impact of apoptosis is due to altered apoptotic behaviour caused by variations of apoptosis-related genes. Instead, apoptosis in MS may also represent a secondary response to cellular stress during acute inflammation in the central nervous system. Here, we screened 202 apoptosis-related genes for association by genotyping 202 microsatellite markers in initially 160 MS patients and 160 controls, both divided in 4 sets of pooled DNA samples, respectively. When applying Bonferroni correction, no significant differences in allele frequencies were detected between MS patients and controls. Nevertheless, we chose 7 markers for retyping in individual DNA samples, thereby eliminating 6 markers from the list of candidates. The remaining candidate, the ERBB3 gene microsatellite, was genotyped in additional $245 \mathrm{MS}$ patients and controls. No association of the ERBB3 marker with the disease was detected in these additional cohorts. In consequence, we did not find further evidence for apoptosis-related genes as predisposition factors in MS.
\end{abstract}

\section{Introduction}

Multiple sclerosis (MS) is among the most common neurological diseases of primarily of young adults [1]. It has predominantly been characterized as a chronic inflammatory disease of the central nervous system (CNS) resulting in myelin and axonal damage and the formation of focal demyelinated plaques. Myelin-reactive T cells enter the
CNS via the blood-brain barrier and mediate the observed inflammatory events [2]. While the contribution of dysfunctional elements from the immune system in MS disease development has been widely accepted from the early days of MS research [3-5], the influence of neuronal death and apoptosis in acute inflammatory plaques has partially been disregarded. Yet, recent insights into the pathogene- 
sis of MS suggest miscellaneous impacts for apoptosis in this neurological disorder, although the contribution to disease susceptibility remains elusive.

Predisposition to the disease depends on both genetic and environmental factors, as demonstrated by twin studies [6] and by virtue of the latitude-dependent geographical distribution [7], thus assigning MS to the large family of common multifactorial diseases, at least in the northern hemisphere. Despite the influence of such predisposing factors, the underlying etiopathological mechanisms as well as most genetic factors responsible for the predisposition to MS remain largely undefined. Until now, the only consistent association has been demonstrated with the HLA-DRB1*1501-DQB1*0602 haplotype in MS patients of European descent [8-10].

Apoptosis, the self-controlled death of cells, is a physiological 'suicide programme' leading to selective elimination of specific cells, either because they become dispensable in their tissue environment or harmful through infection, malignant transformation or, in general, mutation. Regarding MS, impaired apoptosis might result in elevated numbers or extended persistence of myelin-reactive T cells in the CNS tissue, enhancing the observed inflammatory processes $[11,12]$. On the other hand, apoptosis of neuronal cells and their glial chaperones in acute and active MS lesions has recently been demonstrated and may account for most of the disability acquired over time [13-17]. Therefore, when ascertaining candidate genes for MS association studies, factors involved in the regulation and execution of programmed cell death should be considered supplementary to those acting in the dysregulation of the immune system.

We performed an association screen in 202 microsatellite markers in or near to putative MS candidate genes related to apoptosis and the immune system using specifically designed primers and pooled DNA in a case-control design as described previously [18]. Such an 'indirect' approach strictly relies on the presence of linkage disequilibrium (LD) between certain alleles of a microsatellite marker and the corresponding predisposing mutation in the nearby candidate gene. Association was tested by means of contigency tables comparing allele frequencies in MS patients and controls. Subsequently, in case associated markers were found, we performed microsatellite genotyping of individual DNAs, thereby excluding false positive associations resulting from artifact introduced by DNA pooling.

\section{Materials and methods Patient and control DNA samples}

All individuals involved in this study gave written consent for the genetic analyses. Peripheral blood samples from >
600 healthy blood donors were provided by the department of transplantation and immunology of the University hospital Eppendorf (Hamburg, Germany) and the department of transfusion medicine of the University hospital Essen (Essen, Germany). More than 800 unrelated MS patients classified according to the Poser criteria [19] and attending the Departments of Neurology, University clinic of Bochum (Germany), were included. DNA was extracted from peripheral blood leukocytes by standard methods [20]. The quality of each individual DNA was evaluated by separation on $0.7 \%$ agarose gels.

\section{DNA pooling}

The employment of pooled DNA samples in microsatellite genotyping introduces errors [9], unless pooling is performed absolutely accurately. Concentration of DNA from each individual was quantified in triplicate using spectrophotometric measurement and then diluted to a final $50 \mathrm{ng} / \mu \mathrm{l}$. After once more verifying these concentrations twice, 40 individual DNAs were combined into a DNA pool of a final concentration of $25 \mathrm{ng} / \mu \mathrm{l}$. This way, 4 DNA pools were created for MS patients and controls, respectively. Using subpools prevents quantitative errors, as each allele image profile (AIP) of the respective microsatellite is statistically compared to the other subpool of the respective group.

\section{Microsatellite markers}

Intragenic microsatellites or, if not available, microsatellites localised in the immediate vicinity $(<50 \mathrm{~kb})$ of the specific gene were included. For all genes represented by microsatellite markers, oligonucleotide sequences, distances to the specific gene, and additional information are presented in the Markers website http://www.ruhr-unibochum.de/mhg/marker information.pdf. Only markers with equal "intra-subgroup" allele distributions with $\geq 2$ alleles were included in the subsequent analyses. All significantly associated markers $(p \geq 0.05)$ were subsequently genotyped individually (see below).

\section{Tailed primer polymerase chain reaction (PCR)}

We used a universal fluorescence-labelled tailed oligonucleotide added to the $5^{\prime}$ part of the sequence-specific primer for automatic fragment analysis. The tail (5'CATCGCTGATTCGCACAT-3') was designed to be secondary structure prone, and its sequence was "blasted" against the NCBI human genome database [21] yielding no significant homologies. Gene-specific microsatellites were chosen applying the repeat-masker option of the Santa Cruz genome browser [22]. Primers were designed and adjusted to a melting temperature of $55^{\circ} \mathrm{C}$ using the Primer Express 2.0 Software (ABI). Amplification was performed using three oligonucleotides: (1) a tailed forward primer (tailed F), (2) a reverse primer and (3) a labelled primer (labelled F) corresponding to the 5 -tail sequence 
of tailed F. PCR conditions were as follows: $1 \times$ PCR buffer (Qiagen), 1.5 pmol labelled F, $0.2 \mathrm{mM}$ each dNTP, $3 \mathrm{mM}$ $\mathrm{MgCl}_{2}, 0.2 \mathrm{pmol}$ tailed F, $1.5 \mathrm{pmol}$ reverse primer, $0.25 \mathrm{U}$ Qiagen Hot Start Taq (Qiagen) and 50 ng DNA. PCR reactions were performed with an initial activation step at $95^{\circ} \mathrm{C}$ for $15 \mathrm{~min}$; 35 cycles of denaturation at $94^{\circ} \mathrm{C}$ for 1 min, annealing at $55^{\circ} \mathrm{C}$ for $1 \mathrm{~min}$ and extension at $72^{\circ} \mathrm{C}$ for $1 \mathrm{~min}$; and a final extension at $72^{\circ} \mathrm{C}$ for $10 \mathrm{~min}$.

\section{Electrophoresis and genotyping}

Electrophoresis was performed on a 96-well ABI377 slabgel system. Aliquots of $1.0 \mu \mathrm{l}$ PCR product and $2 \mu \mathrm{l}$ of fluorescent ladder (MegaBACE ET400-R Size Standard; Amersham) were mixed. A $1 \mu$ l sample of this mix was loaded onto a $4.5 \%$ polyacrylamide (PAA) gel containing $5.625 \mathrm{ml}$ 40\% (19:1) PAA, $18 \mathrm{~g}$ urea, $5 \mathrm{ml} 10 \times$ TBE buffer (90 mM Tris-borate, 2 mM EDTA, pH 8.3), $25 \mathrm{ml}$ bidistilled $\mathrm{H}_{2} \mathrm{O}, 30 \mu \mathrm{l} 10 \%$ ammoniumpersulphate and $20 \mu \mathrm{l}$ Tetramethylethylendiamin. Prior to polymerisation, the gel mix was filtered through a $0.2-\mu \mathrm{m}$ membrane filter. Electrophoreses were run using ABI standard protocols. Raw data were analysed using the Genotyper software $(\mathrm{ABI})$, resulting in a marker-specific AIP. AIPs consist of a series of peaks with different heights that correspond to the respective allele frequency distribution within each analysed DNA pool.

\section{Statistics for comparison of allele frequencies}

Association was tested by comparison of the MS and control AIPs. Peak heights were normalized according to the number of expected alleles per pool $(n=80)$. Averages of each peak (each distinct allele) were calculated according to the total allele count. Alleles with frequencies $<5 \%$ were added up and considered as one allele. Case and control distributions for combined MS and control pools, respectively, were subsequently compared statistically by means of contingency tables. Hence, $p$ values are nominal and approximate because of the use of estimated rather than observed counts for allele frequencies. In order to select markers for further investigations, non-corrected $p$ values were ranked according to their evidence for association [23]. Markers showing the most significant differences between MS patients and controls were subsequently chosen for further analysis by individual genotyping.

\section{Individual genotyping}

PCR of pooled DNA samples can introduce artifacts that may cause an increased rate of false-positive results, i.e. differences between pools may appear exaggerated. Therefore, the most conspiciously differing markers were genotyped in individual DNA samples of patients and controls, both from the original pools (both $\mathrm{n}=160$ ) as well as additional patient and control cohorts (both $n=245$ ) and under similar conditions as used for pool PCRs. Associa-
Table I: Microsatellites with significant differences $(p<0.05)$ in allele frequencies between MS patients and controls when screened using pooled DNA samples. No correction for multiple testing was applied here.

\begin{tabular}{cc}
\hline Microsatellite & $p$ value \\
\hline NOSI & 0.0068 \\
NFKB2 & 0.0207 \\
FADD & 0.0213 \\
GZMB & 0.0245 \\
ERBB3 & 0.0249 \\
NGF $\beta$ & 0.0292 \\
ADPRT & 0.0335 \\
\hline
\end{tabular}

tion was analysed by comparison of microsatellite allele frequencies from the MS cohort with the corresponding allele of the control group by chi-square testing.

\section{Results and discussion}

The statistical evaluation of 202 microsatellite markers in $160 \mathrm{MS}$ patients and 160 controls combined in 8 DNA pools, each consisting of 40 individuals, respectively, revealed 7 markers with significant differences between allele frequencies of MS patients and controls (Tab. 1).

However, except for NOS1, no marker exceeded borderline significance, and Bonferroni correction for multiple testing $(n=202)$ did eliminate all significant results. Nevertheless, the 4 most promising markers were chosen for further analysis by individual genotyping, thereby excluding possible artifacts introduced via DNA pooling and circumventing the need for massive correction: ERBB3 (Verb-b2 erythroblastic leukemia viral oncogene homologue 3), NFKB2 (nuclear factor of $\kappa$ light polypeptide gene enhancer in B-cells 2), NGF $\beta$ (nerve growth factor $\beta$ ) and NOS1 (nitric oxide synthase 1). The observed allele frequencies of pooled and individual DNA samples are compared in Fig. 1.

Allele frequencies were counted from individual genotypes and compared statistically according to AIP analysis resulting from pooled DNA using the same $160 \mathrm{MS}$ patients and controls. In case additional alleles were detectable, only those alleles that were observed in both experiments were analysed. The results of the statistical tests are shown in table 2.

Apparently, 3 of the 4 comparisons of pooled and individual DNAs show substantial differences. Only the microsatellite near to the ERBB3 gene remained significantly associated when the same DNA samples were retyped individually. For the NFKB2, NGF $\beta$ and NOS1 genes, the comparisons of allele frequencies from pooled and individually-typed DNA samples (Fig. 1) show an important 


\section{ERBB3}

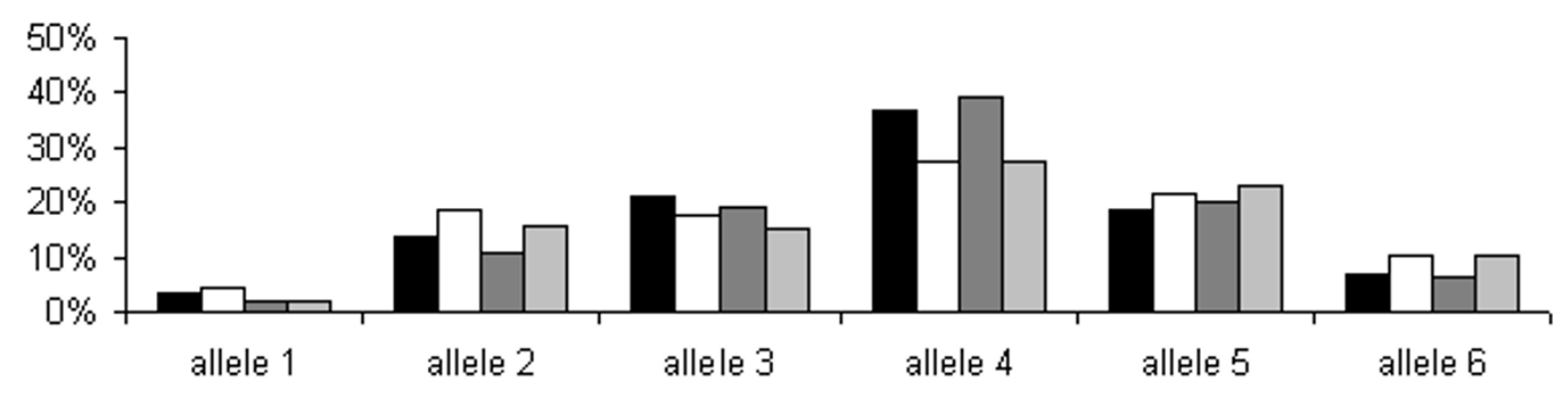

NFKB2

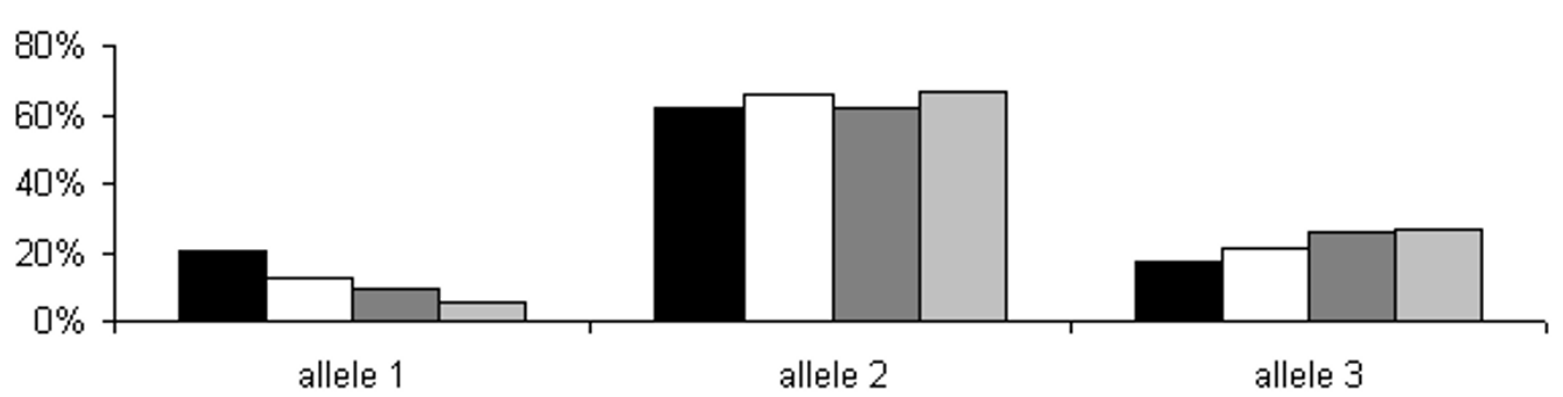

MGFB

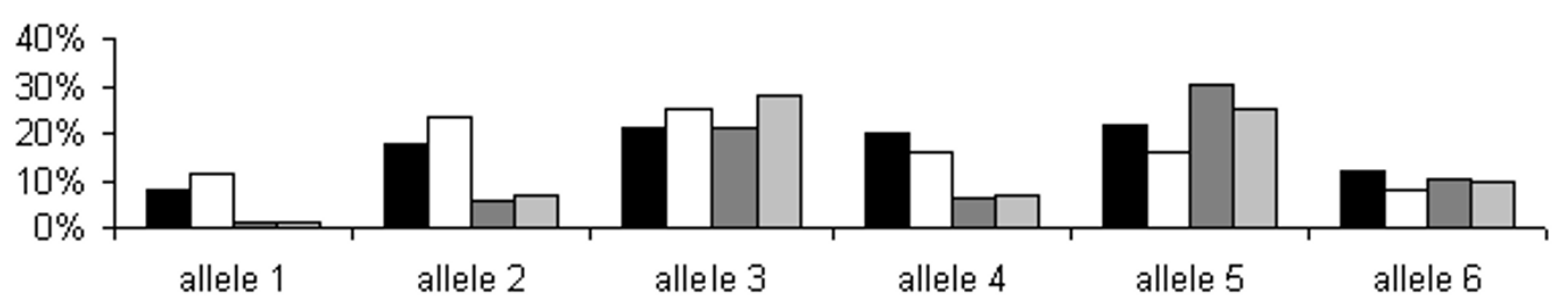

NOS1

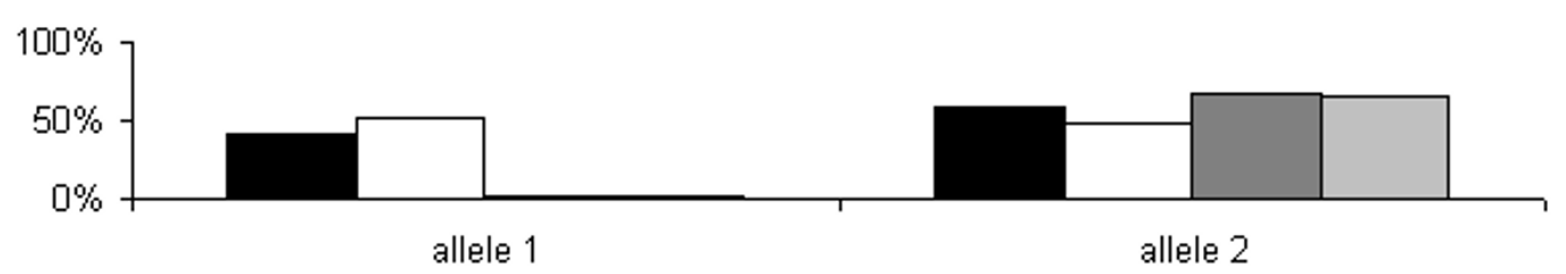

a pooled DNA CO $\square$ pooled DNA MS $\square$ allele frequencies CO $\square$ allele frequencies MS

\section{Figure I}

Allele frequencies genotyped in 4 microsatellite markers using pooled (black and white columns) and individual DNA samples (dark grey and light grey). CO: controls; MS: MS patients. 
Table 2: Relation of $p$ values between analyses based on pooled and individual DNAs using an identical set of $160 \mathrm{MS}$ patient and controls, respectively.

\begin{tabular}{ccc}
\hline Microsatellite & $p$ value (pools) & $p$ value (individual DNAs) \\
\hline ERBB3 & 0.0249 & $0.016^{*}$ \\
NFKB2 & 0.0207 & 0.15 \\
NGF $\beta$ & 0.0292 & 0.44 \\
NOSI & 0.0068 & 0.97 \\
\hline
\end{tabular}

*corrected for multiple testing according Bonferroni $(n=4$ simultaneous tests)

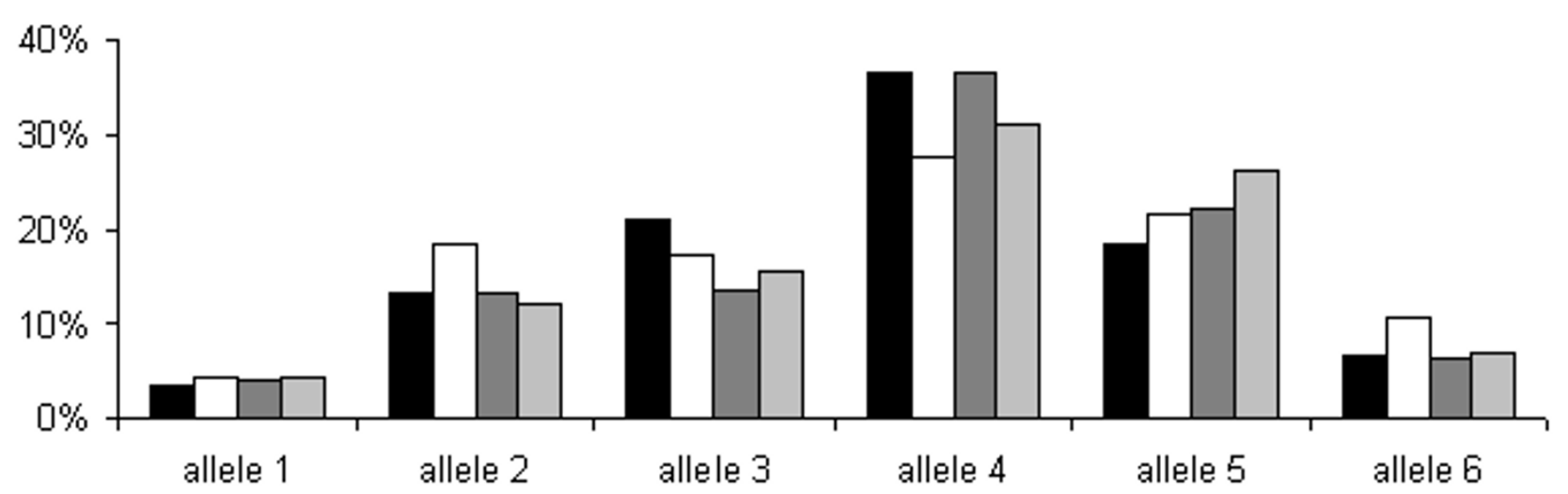

pooled DNA CO $\square$ pooled DNA MS $\square$ allele frequencies CO $\square$ allele frequencies MS

Figure 2

Allele frequencies genotyped in the microsatellite ERBB3 using the originally pooled (black and white columns) and the additional 490 individual DNA samples (dark grey and light grey). CO: controls; MS: MS patients.

and typical artifact [9]. DNA polymerases tend to preferentially amplify short alleles in favour of longer alleles (length-dependent amplification). Therefore, in PCRs based on pooled DNA samples, the shorter alleles of a microsatellite marker will often be over-represented in the resulting PCR product. This effect is most apparent in the marker NOS1, where one of the observed alleles in the pooled experiment obviously results exclusively from the abovementioned effect. Also in NGF $\beta$, the alleles 1 and 2 were significantly over-represented in the screen using pooled DNA, resulting in a false positive association. Only for the ERBB3 gene, the observed allele frequencies in the typing experiment based on pooled DNA adequately correspond to the individually typed frequencies.

In order to validate the association of ERBB3 with MS, we performed genotyping of another cohort of 245 MS patients and controls, respectively (frequencies shown in Fig. 2).

Statistical analysis of the latter allele frequency distribution revealed a non significant $p$ value of 0.325 . Therefore, the association of the ERBB3 microsatellite could not be confirmed in the additional DNA cohorts of MS patients and controls.

In conclusion, we did not find supporting evidence for involvement of apoptosis-related genes in the predisposition to MS. Nevertheless, such a contribution cannot be excluded based exclusively on our experiments for various reasons. Only a fraction of all apoptosis-related genes has been included in our survey and, therefore, many more genes may represent auspicious candidates. Moreover, as our approach depends solely on the presence of LD between a marker and a predisposing mutation, missing 
LD between the microsatellite and its corresponding gene will also cause a negative result. As the HapMap-Project [24] progresses rapidly and, therefore, information about the haplotype block structure of the human genome increases substantially, it might soon be possible to reappraise our negative results with respect to the haplotype block structure of the gene under examination.

\section{References}

I. Poser CM: The epidemiology of multiple sclerosis: a general overview. Ann Neurol 1994, 36 Suppl 2:SI80-93.

2. Hemmer B, Cepok S, Nessler S, Sommer N: Pathogenesis of multiple sclerosis: an update on immunology. Curr Opin Neurol 2002, I 5(3):227-23I.

3. livanainen MV: The significance of abnormal immune responses in patients with multiple sclerosis. J Neuroimmunol I98I, I(2): I4I-172.

4. Lisak RP, Zweiman B, Burns JB, Rostami A, Silberberg DH: Immune responses to myelin antigens in multiple sclerosis. Ann $N Y$ Acad Sci 1984, 436:22I-230.

5. Waksman BH, Reynolds WE: Multiple sclerosis as a disease of immune regulation. Proc Soc Exp Biol Med 1984, 175(3):282-294.

6. Willer CJ, Dyment DA, Risch NJ, Sadovnick AD, Ebers GC: Twin concordance and sibling recurrence rates in multiple sclerosis. Proc Natl Acad SciU S A 2003, I00(22): I 2877- I 2882.

7. Sotgiu S, Pugliatti M, Fois ML, Arru G, Sanna A, Sotgiu MA, Rosati G: Genes, environment, and susceptibility to multiple sclerosis. Neurobiol Dis 2004, I 7(2): 131-I43.

8. Epplen C, Jackel S, Santos EJ, D'Souza M, Poehlau D, Dotzauer B, Sindern E, Haupts M, Rude KP, Weber F, Stover J, Poser S, Gehler W, Malin JP, Przuntek H, Epplen JT: Genetic predisposition to multiple sclerosis as revealed by immunoprinting. Ann Neurol 1997, 4I(3):34I-352.

9. Godde R, Nigmatova V, Jagiello P, Sindern E, Haupts M, Schimrigk S, Epplen JT: Refining the results of a whole-genome screen based on $\mathbf{4 6 6 6}$ microsatellite markers for defining predisposition factors for multiple sclerosis. Electrophoresis 2004, 25(I4):22I2-22I8.

10. Goedde R, Sawcer S, Boehringer S, Miterski B, Sindern E, Haupts M, Schimrigk S, Compston A, Epplen JT: A genome screen for linkage disequilibrium in HLA-DRB I*15-positive Germans with multiple sclerosis based on 4666 microsatellite markers. Hum Genet 2002, I I I(3):270-277.

II. Ohsako S, Elkon KB: Apoptosis in the effector phase of autoimmune diabetes, multiple sclerosis and thyroiditis. Cell Death Differ 1999, 6(I):|3-2|.

12. Pender MP: Genetically determined failure of activationinduced apoptosis of autoreactive T cells as a cause of multiple sclerosis. Lancet 1998, 35 I (9107):978-98I.

13. Aktas O, Wendling U, Zschenderlein R, Zipp F: [Apoptosis in multiple sclerosis. Etiopathogenetic relevance and prospects for new therapeutic strategies]. Nervenarzt 2000, 7 I(10):767-773.

14. Meyer R, Weissert R, Diem R, Storch MK, de Graaf KL, Kramer B, Bahr M: Acute neuronal apoptosis in a rat model of multiple sclerosis. J Neurosci 200I, 2I(16):62I4-6220.

15. Oren A, White LR, Aasly J: Apoptosis in neurones exposed to cerebrospinal fluid from patients with multiple sclerosis or acute polyradiculoneuropathy. I Neurol Sci 200I, I86(I2):31-36.

16. Pender MP: Oligodendrocyte apoptosis before immune attack in multiple sclerosis? Ann Neurol 2005, 57(1): 158; author reply 158-9.

17. Zipp F: Apoptosis in multiple sclerosis. Cell Tissue Res 2000, $301(1): 163-171$.

18. Jagiello P, Gencik M, Arning L, Wieczorek S, Kunstmann E, Csernok E, Gross WL, Epplen JT: New genomic region for Wegener's granulomatosis as revealed by an extended association screen with 202 apoptosis-related genes. Hum Genet 2004, I I 4(5):468-477.

19. Poser CM, Paty DW, Scheinberg L, McDonald WI, Davis FA, Ebers GC, Johnson KP, Sibley WA, Silberberg DH, Tourtellotte WW: New diagnostic criteria for multiple sclerosis: guidelines for research protocols. Ann Neurol 1983, I3(3):227-231.
20. Miller SA, Dykes DD, Polesky HF: A simple salting out procedure for extracting DNA from human nucleated cells. Nucleic Acids Res 1988, 16(3): 1215.

21. McGinnis S, Madden TL: BLAST: at the core of a powerful and diverse set of sequence analysis tools. Nucleic Acids Res 2004, 32(Web Server issue):W20-5.

22. Karolchik D, Baertsch R, Diekhans M, Furey TS, Hinrichs A, Lu YT, Roskin KM, Schwartz M, Sugnet CW, Thomas DJ, Weber RJ, Haussler D, Kent W]: The UCSC Genome Browser Database. Nucleic Acids Res 2003, 3 I (I):5I-54.

23. Setakis E: Statistical analysis of the GAMES studies. J Neuroimmunol 2003, I 43( I-2):47-52.

24. Consortium TIHM: The International HapMap Project. Nature 2003, 426(6968):789-796.
Publish with Biomed Central and every scientist can read your work free of charge

"BioMed Central will be the most significant development for disseminating the results of biomedical research in our lifetime."

Sir Paul Nurse, Cancer Research UK

Your research papers will be:

- available free of charge to the entire biomedical community

- peer reviewed and published immediately upon acceptance

- cited in PubMed and archived on PubMed Central

- yours - you keep the copyright

Submit your manuscript here:

http://www.biomedcentral.com/info/publishing_adv.asp
BioMedcentral 